\title{
KEGIATAN MEROBEK DENGAN MEDIA KERTAS DAPAT MENINGKATKAN KETERAMPLAN MOTORIK HALUS PADA ANAK USIA DINI DI KELOMPOK B TK PERTIWI I KOTA JAMBI
}

\author{
Samsidar \\ TK Pertiwi I Kota Jambi \\ Email: samsidar@gmail.com
}

\begin{abstract}
ABSTRAK
Penelitian ini bertujuan untuk meningkatkan keterampilan motorik halus melalui kegiatan menggunting dengan berbagai media pada anak usia dini di kelompok B TK Pertiwi I Kota Jambi Penelitian ini merupakan penelitian tindakan kelas kolaboratif yang dilaksanakan dalam 2 siklus.

Peningkatan kemampuan motorik halus dikatakan berhasil apabila persentase kemampuan motorik halus anak mencapai $80 \%$ dengan kriteria baik. Hasil penelitian keterampilan motorik halus Pra Tindakan kriteria kurang baik dengan nilai rata-rata keterampilan motorik halus sebesar $47.3 \%$. Hasil penelitian Siklus I kriteria cukup dengan nilai rata-rata keterampilan motorik halus sebesar $62.2 \%$. Setelah dilakukan tindakan pada siklus I telah berhasil meningkatkan keterampilan motorik halus tetapi belum mencapai indikator keberhasilan sehingga diperlukan siklus selanjutnya.

Hasil Siklus II pencapaian kriteria baik dengan nilai rata-rata keterampilan motorik halus sebesar $84.1 \%$. Peningkatan ini diperoleh melalui kegiatan menggunting dengan berbagai media dengan langkah-langkah pembelajaran yaitu: (1).menyiapkan media dan alat yang digunakan di kegiatan merobek dan menggunting, (2).memberikan contoh cara menggunting sesuai pola gambar, (3).membagikan media dan alat yang digunakan dalam kegiatan merobek dan menggunting secara proporsional untuk setiap kelompok, (4).anak diperkenankan melakukan kegiatan menggunting dengan berbagai media sesuai dengan contoh yang diberikan oleh guru.
\end{abstract}

Kata kunci: keterampilan motorik halus, kegiatan menggunting dengan berbagai media.

\section{A. PENDAHULUAN}

\section{Latar Belakang Masalah}

Pendidikan harus di mulai sejak dini, untuk memantapkan karakter anak hingga dewasa, untuk membentuk karakter anak, dilakukan dengan proses pendidikan yang bermutu dan berkelanjutan.(Sumarto, 2018) Pendidikan anak usia dini merupakan pendidikan yang diselenggarakan untuk mengembangkan keterampilan yang merupakan pendidikan dasar serta mengembangkan diri secara 
utuh sesuai dengan asas pendidikan sedini mungkin dan sepanjang hayat. Aspek yang dikembangkan dalam pendidikan anak usia dini adalah aspek pengembangan pembiasaan meliputi sosial, emosi, kemandirian, moral, dan nilai-nilai agama, serta pengembangan kemampuan dasar yang meliputi pengembangan bahasa, kognitif, dan fisik motorik Bredekamp \& Copple, menurut Tadkiroatun Musfiroh (2008: 4).

Perkembangan pada anak usia dini mencakup perkembangan fisik dan motorik, kognitif, sosial emosional dan bahasa. Pada masa ini anak sudah memiliki keterampilan dan kemampuan walaupun belum sempurna. Usia anak pada masa ini merupakan fase foundamental yang akan menentukan kehidupannya dimasa datang. Untuk itu, kita harus memahami perkembangan anak usia dini khususnya perkembangan fisik dan motorik.

Penguasaan keterampilan motorik juga dapat memacu anak untuk menekuni bidang tertentu sejak dini seperti bermain musik, melukis, membuat kerajinan, membuat gambar desain, dan lain sebagainya. Banyak sekali anak usia muda yang menonjol bakatnya karena kemampuan motorik halus yang baik. Husein dkk (Sumantri, 2005 :2) menguraikan bahwa pembinaan dan pengembangan potensi anak bangsa dapat diupayakan melalui pembangunan di berbagai bidang yang di dukung oleh atmosfer masyarakat belajar.

Anak usia dini mempunyai potensi yang demikian besar untuk mengoptimalkan segala aspek perkembangannya, termasuk perkembangan motoriknya artinya perkembangan keterampilan motorik sebagai perkembangan unsur kematangan dan pengendali gerak tubuh. Anak usia dini yang berusia 2-5 tahun memiliki energi tinggi.

Energi yang dibutuhkan untuk melakukan berbagai aktivitas yang diperlukan dalam meningkatkan keterampilan fisik, baik yang berkaitan dengan keterampilan motorik halus, seperti menggunting dan menempel, membentuk atau memanipulasi dari tanah liat/lilin/adonan, menggambar, mewarnai, memotong, merangkai benda dengan benang (meronce).

Aktivitas keterampilan motorik halus anak Taman Kanak-kanak bertujuan untuk melatihkan keterampilan koordinasi motorik anak diantaranya koordinasi 
antara tangan dan mata yang dapat dikembangkan melalui kegiatan bermain (Sumantri, 2005: 145).

Proses perkembangan sensorik motorik pada Pendidikan Taman Kanakkanak seyogyanya mendapat perhatian pendidik dengan benar. Guru sebagai salah satu kunci keberhasilan pembelajaran di Taman Kanak-kanak seyogyanya selalu mengupayakan agar pembelajaran berlangsung sesuai kaidah-kaidah pembelajaran.

Pembelajaran dapat berlangsung dengan baik jika guru mampu memerankan perannya sebagai pembaharu, motivator, inovator dalam setiap langkah menjalankan tugasnya sebagai guru. Berdasarkan pengamatan di TK B Pertiwi I Kota Jambi belum begitu berkembang. Beberapa anak menunjukkan keterlambatan dalam keterampilan motorik halusnya terutama menggunting, yang ditandai dengan belum terampilnya anak dalam merobek dan menggunting.

Dari 15 anak tercatat sebanyak 7 anak yang masih belum tepat dalam merobek atau menggunting sesuai garis atau belum mengikuti garis batas. Ada 4 anak yang cara memegang guntingnya belum benar dengan menggunakan dua jarinya saja sehingga hasil guntingannya kurang ada penekanan dan kertas yang digunting sulit untuk diguntingnya. Ada 4 anak yang cepat selesai mengguntingnya sehingga hasilnya masih kurang rapi dan asal-asalan, akan tetapi ada 8 anak yang mengerjakannya dengan mampu dan terampil sehingga hasilnya sesuai harapan.

Kasus di atas menyebutkan bahwa anak kelompok B mengalami kesulitan dalam pengembangan motorik halus, dapat disebabkan oleh beberapa faktor seperti pengembangan keterampilan anak usia dini seringkali terabaikan atau dilupakan oleh orang tua, pembimbing atau bahkan guru sendiri. Faktor penyebab yang lain yaitu lemahnya koordinasi mata dan otot-otot tangan.

Berdasarkan hasil pengamatan aktivitas pembelajaran motorik halus, guru belum menggunakan media lain yang lebih variatif dalam kegiatan menggunting sehingga anak kurang tertarik dan mengakibatkan kurang optimalnya perkembangan motorik halus. Berdasarkan deskripsi di atas diperlukan adanya kegiatan pembelajaran yang dapat meningkatkan keterampilan motorik halus 
anak. Salah satu kegiatan pembelajaran yang dapat meningkatkan keterampilan motorik halus anak yaitu kegiatan menggunting dengan berbagai media. Kegiatan menggunting bertujuan untuk melatih koordinasi mata dan otot-otot tangan serta konsentrasi. Keterampilan merobek/menggunting bisa menjadi tahap persiapan awal anak menulis terutama saat memegang pensil.

Kegiatan merobek yang akan dikembang lebih lanjut dengan kegiatan menggunting salah satu stimulus yang dapat dikembangkan oleh pendidik dalam mengembangkan motorik anak terutama motorik halus anak. Anak akan mampu mengkoordinasi indra mata dan aktivitas tangan melalui kegiatan menggunting.

Hal ini akan merugikan anak dalam menghadapi masa depannya, keluarga dan bangsa. Pada masa kanak-kanak penyerapan informasi akan berlangsung sangat cepat, sehingga pada masa ini anak akan banyak melakukan peniruan terhadap bahasa, emosional, dan perilaku yang melibatkan gerakan-gerakan tubuh anak, dan ini dikenal dengan masa the golden age (Slamet Suyanto, 2005: 6).

Pendidikan Taman Kanak-kanak modern tidak memperhatikan salah satu aspek secara parsial (bagian) melainkan pendidikan secara menyeluruh terhadap komponen terkait pada diri anak. Pertumbuhan pada masa ini perlu mendapat rangsangan untuk menerima informasi yang bermanfaat bagi anak, serta mengembangkan sikap sosial emosional. Seiring dengan pertumbuhan otak, maka pertumbuhan jasmani penting untuk diperhatikan.

Peneliti menggunakan berbagai media dalam kegiatan menggunting, karena dengan berbagai media dapat melatih anak mulai dari tahap menggunting awal sampai sulit. Anak dapat menyesuaikan ketebalan media yang digunakan maupun bahan yang digunakan mulai dari tingkat kesulitan yang temudah sampai tahap menggunting akhir dengan berbagai media tersebut.

Selain itu dengan berbagai media yang gunakan dalam kegiatan menggunting menjadikan pembelajaran lebih bervariasi sehingga diharapkan anak lebih aktif dan menarik minat anak dalam mengikuti pembelajaran.

Dari uraian diatas maka penulis mengambil judul “ Kegiatan Merobek dengan media kertas Dapat Meningkatkan Kterampilan Motorik Halus pada usia dini Kelompok B TK Pertiwi I Kota Jambi ” 


\section{Rumusan masalah}

Berdasarkan uraian batasan masalah tersebut di atas, maka rumusan yang diajukan adalah bagaimana meningkatan kemampuan motorik halus melalui kegiatan menggunting dengan berbagai media pada anak usia dini di kelompok B TK Pertiwi I Kota Jambi?.

\section{Tujuan}

Berdasarkan rumusan masalah di atas, penelitian ini bertujuan untuk meningkatkan keterampilan motorik halus melalui kegiatan menggunting dengan berbagai media pada kelompok B TK Pertiwi I Kota Jambi.

\section{Manfaat}

a. Bagi pendidik

1) Menambah pengetahuan dalam menggunakan variasi metode pembelajaran untuk meningkatkan keterampilan motorik halus.

2) Meningkatkan keterampilan guru dalam mengembangkan dan melaksanakan pembelajaran yang bervariasi.

b. Bagi peserta didik

1) Meningkatkan keterampilan motorik halus anak.

2) Memperoleh pengalaman langsung mengenai menggunting dengan berbagai media.

\section{B. LANDASAN TEORI}

\section{Keterampilan Motorik Halus}

Menurut Mahendra (Sumantri, 2005: 143) keterampilan motorik halus (fine motor skill) merupakan keterampilan yang memerlukan kemampuan untuk mengontrol otot-otot kecil atau halus untuk mencapai pelaksanaan keterampilan yang berhasil. Magill (Sumantri, 2005: 143) keterampilan ini melibatkan koordinasi neuromuscular (syaraf otot) yang memerlukan ketepatan derajat tinggi untuk berhasilnya keterampilan ini. Keterampilan jenis ini sering disebut sebagai keterampilan yang memerlukan koordinasi mata dan tangan, (hand-eye coordination). Menulis, menggambar, menggunting, bermain piano adalah contoh-contoh keterampilan tersebut. Dari beberapa pendapat di atas dapat 
disimpulkan bahwa keterampilan motorik halus adalah penggunaan sekelompok otot-otot kecil. Seperti jari-jari jemari dan tangan yang membutuhkan kecermatan serta koordinasi mata dan tangan untuk mengontrol dalam mencapai pelaksanaan keterampilan. Contoh keterampilan yang dimiliki anak usia 4 sampai 5 tahun yaitu menulis, menggambar, menggunting, membentuk, mengancingkan baju, memanipulasi, menjiplak bentuk.

Tujuan dari keterampilan motorik halus (Yudha M. Saputra \& Rudyanto (2005: 115) yaitu:

a. Mampu memfungsikan otot-otot kecil seperti gerakan jari tangan.

b. Mampu mengkoordinasi kecepatan tangan dan mata.

c. Mampu mengendalikan emosi.

Sedangkan fungsi motorik (Toho dan Gusril (2004: 51) ialah mengembangkan kesanggupan dan keterampilan setiap individu yang berguna untuk mempertinggi daya kerja. Lebih lanjut dijelaskan bahwa dengan mempunyai keterampilan motorik yang baik, tentu individu mempunyai landasan untuk menguasai tugas keterampilan yang khusus.

Dari beberapa pendapat tersebut dapat disimpulkan bahwa fungsi keterampilan motorik halus erat kaitanya dengan keterampilan hidup anak untuk memposisikan diri pada kehidupannya yang lebih baik serta mendukung aspek pengembangan lainnya seperti aspek pengembangan kognitif, aspek pengembangan bahasa, dan aspek pengembangan sosial.

Kegiatan pengembangkan anak usia dini harus senantiasa berorientasi pada kebutuhan anak. Anak usia dini adalah masa yang sedang membutuhkan stimulasi secara tepat untuk mencapai optimalisasi seluruh aspek pengembangan fisik maupun psikis. Dengan demikian, ragam jenis kegiatan pembelajaran hendaknya dilakukan melalui analisis kebutuhan yang disesuaikan dengan berbagai aspek perkembangan dan kemampuan pada masing-masing anak.

Upaya stimulasi yang diberikan pendidik terhadap anak usia (4-6 tahun) hendaknya dilakukan dalam situasi yang menyenangkan. Menggunakan pendekatan bermain 15 anak diajak untuk bereksplorasi, menemukan, dan 
memanfaatkan obyek-obyek yang dekat denganya sehingga diharapkan kegiatan akan lebih bermakna.

Aktifitas kreatif dan inovatif dapat dilakukan oleh pendidik melalui kegiatan yang menarik, membangkitkan rasa ingin tahu, memotivasi anak untuk berfikir kritis, dan menemukan hal-hal baru. Lingkungan harus diciptakan sedemikian menarik, sehingga anak akan betah. Lingkungan fisik hendaknya memperhatikan keamanan dan kenyamanan anak dalam bermain.

Penataan ruang harus senantiasa disesuaikan dengan ruang gerak anak dalam bermain dan tidak menghalangi interaksi dengan pendidik atau dengan temannya. Jika kegiatan yang dilakukan memanfaatkan tema, maka pemilihan tema hendaknya disesuaikan dari hal-hak yang paling dekat dengan anak, sederhana, dan menarik minat anak. Penggunaan tema dimaksudkan agar anak mampu mengenali berbagai konsep secara mudah dan jelas.

\section{Kegiatan Merobek}

Kegiatan merobek bukanlah sesuatu yang "main-main". Keterampilan jemari yang diasah melalui kegiatan ini adalah sesuatu yang penting, sebaiknya tidak melarangnya dengan serta-merta. Latihan ini perlu dilakukan, tetapi dengan alat atau media yang tepat. Misalnya, kertas bekas atau daur ulang, atau buku tulis yang memang Anda sediakan untuk dirobek-robek.

Selain untuk latihan motorik halus, kegiatan merobek sebenarnya juga melatih kecerdasan emosi anak, terutama untuk mengendalikan dorongan atau emosi. Anak usia ini memang suka menggebu-gebu dalam segala hal. Maklum, ia sedang "memasuki" zona penuh tantangan bagi orang tua: the terrible two's. Merobek kertas, adalah salah satu aktivitas motorik halus untuk anak usia dini. Khususnya anak berkebutuhan khusus seperti anak autis.

\section{Menggunting}

Menggunting merupakan kegiatan kreatif yang menarik bagi anak-anak. Menggunting termasuk teknik dasar untuk membuat aneka bentuk kerajinan tangan, bentuk hiasan dan gambar dari bahan kertas dengan memakai bantuan alat 
pemotong. Sumantri (2005: 152) mengemukakan bahwa menggunting adalah memotong berbagai aneka kertas atau bahan-bahan lain dengan mengikuti alur, garis atau bentuk-bentuk tertentu merupakan salah satu kegiatan yang mengembangkan motorik halus anak.

Koordinasi mata dan tangan dapat berkembang melalui kegiatan menggunting. Saat menggunting jari jemari anak akan bergerak mengikuti pola bentuk yang digunting. Suratno (2005: 126) menyatakan bahwa kegiatan menggunting membutuhkan keterampilan menggerakkan otot-otot tangan dan jari-jari untuk berkoordinasi dalam menggunting sehingga bisa memotong kertas, kain atau yang lain sesuai yang diinginkan; seperti menggunting yang berpola, menggunting dan melipat untuk membentuk gambar, membentuk pola ataupun yang lain. Jamaris (Sumantri, 2005: 181) mengemukakan bahwa anak yang mengalami kesulitan belajar gerak motorik adalah lemahnya koordinasi gerak visual motorik yaitu anak yang mengalami kesulitan dalam melakukan koordinasi antara gerak visual (pandangan mata) dan motorik (gerakan tangan, gerakan jari tangan atau kaki) secara serempak dan terarah pada satu tujuan seperti yang dilakukan pada waktu memasukkan benang ke dalam lobang jarum atau pada waktu mewarnai gambar atau merobek dan menggunting kertas.

Dari beberapa pendapat di atas dapat disimpulkan bahwa kegiatan menggunting salah satu stimulus yang dapat dikembangkan oleh pendidik dalam mengembangkan motorik anak terutama motorik halus anak. Anak akan mampu mengkoordinasi indra mata dan aktivitas tangan melalui kegiatan menggunting. Pada usia 4- 6 tahun anak sangat memerlukan stimulus yang mengembangkan segala aspek perkembangan usianya baik motorik, kognitif, nilai agama dan moral, bahasa, seni, serta sosial emosional anak.

Sumantri (2005: 157) mengemukakan manfaat kegiatan menggunting untuk mengembangkan keterampilan, melatih koordinasi tangan dan mata, dan konsentrasi yang merupakan persiapan awal atau pengenalan kegiatan menulis. Kegiatan menggunting sangat bermanfaat untuk mengembangkan keterampilan anak dalam menggerakkan otot-otot tangan dan jari-jari anak. Suratno (2005: 127) 
menyatakan bahwa kegiatan menggunting dapat melatih otot tangan dan jari anak serta melatih konsentrasi anak.

Kegiatan menggunting merupakan kegiatan kreatif yang menarik bagi anak-anak. Menggunting membutuhkan langkah kerja yang memudahkan anak untuk melakukannya.

\section{METODOLOGI PENELITIAN}

\section{Jenis Penelitian}

Penelitian yang dilakukan merupakan Penelitian Tindakan Kelas (PTK). Penelitian kelas yang yang dimaksud adalah tindakan untuk meningkatkan mutu pembelajaran dimana tindakan tersebut dianggap sebagai cara yang tepat.

\section{Subjek Penelitian}

Dalam penelitian ini yang menjadi subjek penelitian adalah anak kelompok B di TK Pertiwi I Kota Jambi sebanyak 19 anak.

\section{Waktu dan Tempat Penelitian}

Penelitian ini dilaksanakan pada Semester II Tahun ajaran 2018/2019 pada yang diawali survei awal, penyusunan instrumen, kemudian dilanjutkan dengan analisis data dan proses pelaporan. Penelitian dilaksanakan di kelompok B TK Pertiwi I Kota Jambi

\section{Model Penelitian}

Model penelitian ini mengacu pada model penelitian tindakan kelas dari Kemmis dan Mc Taggart sebagaimana dikutip Sujati (2000: 23), yang dalam kegiatan menggunakan siklus sistem spiral. Masing-masing siklus terdiri dari empat komponen pokok yaitu perencanaan, perlakuan atau tindakan, pengamatan dan refleksi.

\section{Teknik Pengumpulan Data}

Teknik pengumpulan data yang diperlukan dalam penelitian ini adalah: observasi. Observasi yang digunakan dalam penelitian ini mengacu pada pendapat Rochiati Wiriatmadja (2006: 107) yaitu observasi partisipasi lengkap yang artinya dalam melakukan pengumpulan data, peneliti terlibat sepenuhnya dalam 36 pembelajaran yang dilakukan sumber data. 


\section{Instrumen Pengumpulan}

Alat yang digunakan untuk mengumpulkan data dalam penelitian ini adalah lembar instrumen observasi.

\section{HASIL PENELITIAN}

Kemampuan Awal Sebelum Tindakan Langkah awal sebelum diadakan penelitian tindakan kelas, peneliti melakukan pengamatan terhadap keterampilan motorik halus anak dengan media pola gambar yang ada pada majalah tanpa menggunakan berbagai media. Nilai yang diperoleh dari kemampuan awal sebelum tindakan ini nantinya akan dibandingkan dengan nilai yang diperoleh setelah diadakannya suatu tindakan keterampilan motorik halus melalui berbagai media. Dengan adanya perbandingan antara nilai sebelum dilakukan tindakan dan setelah dilakukan tindakan maka diharapkan akan terlihat lebih jelas suatu peningkatan sebelum dilakukan tindakan.

Data perkembangan hasil penelitiaan merobek dan menggunting

\begin{tabular}{|c|c|c|c|c|c|}
\hline \multirow[t]{2}{*}{ No. } & \multirow[t]{2}{*}{ Nama Anak } & \multicolumn{4}{|c|}{ Hasil Penelitian } \\
\hline & & BSB & $\mathrm{BSH}$ & $\mathrm{MB}$ & $\mathrm{BB}$ \\
\hline 1. & DINDA & & $\sqrt{ }$ & & \\
\hline 2. & AMANDA & & & $\sqrt{ }$ & \\
\hline 3. & ASSYFA & & & & $\sqrt{ }$ \\
\hline 4. & AZKI & & & $\sqrt{ }$ & \\
\hline 5. & FAHIRAH & & & & $\sqrt{ }$ \\
\hline 6. & INDRI & & & $\sqrt{ }$ & \\
\hline 7. & AFIF & & & $\sqrt{ }$ & \\
\hline 8. & ALIF & & & $\sqrt{ }$ & \\
\hline 9. & HABIB & & & & $\sqrt{ }$ \\
\hline 10. & NUGIE & $\sqrt{ }$ & & $\sqrt{ }$ & \\
\hline 11. & PANGGI & & $\sqrt{ }$ & & \\
\hline 12. & RAFAEL & & & & $\sqrt{ }$ \\
\hline 13. & RESKY & & $\sqrt{ }$ & & \\
\hline
\end{tabular}




\begin{tabular}{|l|l|l|l|l|l|}
\hline 14. & SANDY & & $\sqrt{ }$ & \\
\hline 15. & SIFA & & & $\sqrt{ }$ & \\
\hline
\end{tabular}

Keterangan :

$$
\text { Belum Berkembang 0\% - 25\% }
$$

(MB) Mulai Berkembang 26\% - 50\%

(BSH) Berkembang Sesuai Harapan $51 \%-75 \%$

(BSB) Berkembang Sangat Baik $76 \%-100 \%$

Penelitian tindakan kelas ini telah dilaksanakan oleh peneliti dan guru kelas dengan sungguh-sungguh dan optimal untuk mencapai hasil yang diharapkan. Namun didalamnya masih terdapat banyak kekurangan yaitu:

1. Secara teoritis peneliti mengalami keterbatasan dalam menemukan referensi terkait dengan kegiatan menggunting.

2. Kondisi kelas yang ramai atau kondusif sangat mempengaruhi konsentrasi anak dalam melakukan kegiatan menggunting.

3. Peneliti belum menggunakan evaluasi pembelajaran yang terbaru.

\section{E. KESIMPULAN IMPLIKASI DAN SARAN}

\section{Kesimpulan}

Peningkatan kemampuan motorik halus anak merupakan salah satu yang dipengaruhi oleh pembelajaran motorik halus anak yang diterapkan dalam kegiatan melipat. Kegiatan melipat ini dapat meningkatkan kemampuan motorik halus karena penerapannya melalui kegiatan melipat. Selain itu dalam kegiatan melipat ini peneliti kenalkan bentuk-bentuk lipatan lebih dari satu lipatan.

Pada kegiatan melipat ini juga fleksibel karena penerapannya dapat dipadukan dengan bernyanyi, demonstrasi, penugasan, unjuk kerja dan tanya jawab. Kesimpulan dari analisis dan pembahasan tentang ;penelitian telah dijabarkan di atas yaitu kegiatan melipat dapat meningkatkan kemampuan motorik halus anak kelompok B di TK Pertiwi I Kota Jambi. 
Hal ini terbukti dengan adanya peningkatan prosentase kemampuan motorik halus anak sesuai indikator kinerja yang telah ditentukan dari sebelum tindakan sampai dengan siklus III. Yakni sebelum tindakan 26.3\%, siklus I mencapai $31.9 \%$, siklus II mencapai $54.7 \%$ dan siklus III mencapai $88.3 \%$. Hasil ini melebihi target peneliti yang menmtargetkan $80 \%$ keberhasilan dari tindakan I (siklus I), tindakan II (siklus II) dan tindakan III (siklus III), dengan kegiatan yang berbeda-beda disetiap pertemuan menjadikan anak lebih kreatif 15 dan mempunyai semangat untuk mengembangkan motorik halus melalui kegiatan melipat.

\section{Implikasi}

Keberhasilan peningkatan motorik halus anak melalui kegiatan merobek dan menggunting memberikan sebagai berikut:

1. Dalam memberikan kegiatan melipat untuk anak usia pra sekolah hendaknya kegiatan pembelajaran yang diterapkan disesuaikan dengan karakteristik dan tahap perkembanagn anak.

2. Kegiatan melipat diterapkan untuk meningkatkan kemmapuan motorik halus anak.

\section{Saran}

- Kepala TK

1. Perlu adanya bimbingan kepada guru kelas agar lebih terampil dalam melatih motorik halus, agar anak lebih terampil dalam menggerakkan jari tangan untuk kelenturan, kekuatan dan koordinasi.

2. Perlu adanya perhatian kepada anak dalam melatih otot-otot tangan saat melipat kertas, karena sebagian anak dalam melipat kerts belum bisa dan sebagian besar masih banyak bimbingan atau perhatian lebih agar bisa melipat kertas dengan baik.

- Kepada Guru

1. Guru TK diharapkan mampu melaksanakan pembelajaran sesuai kurikulum.

2. Guru TK hendaknya memperhatikan karakteristik dan tahap perkembangan anak dalam memberi pembelajaran atau kegiatan. 
3. Guru TK harus mampu menciptakan suasana belajar yang menarik dan menyenangkan.

4. Kegiatan melipat perlu diberikan secara konsisten untuk menstimulasi kemampuan motorik halus anak usia dini.

- Kepada Orang Tua

1. Sediakan waktu khusus untuk melatih motorik halus melalui kegiatan melipat kertas.

2. Sabar dalam melatih motorik halus anak, jangan terlalu memaksa anak untuk bisa agar anak tidak merasa tertekan.

Berdasarkan hasil penelitian yang telah dilakukan dapat disimpulkan bahwa keterampilan motorik halus anak pada kelompok B TK Pertiwi I Kota Jambi dapat meningkat dalam kegiatan menggunting dengan berbagai media. Proses pembelajaran kegiatan merobek dan menggunting dilakukan secara bertahap sesuai langkah-langkah pembelajaran, sehingga kemampuan motorik halus anak dapat meningkat secara bertahap.

Melalui perancangan kegiatan yang memungkinkan anak berubah kelompok dan bergantian pembelajaran khususnya untuk aspek keterampilan motorik halus. Penggunaan berbagai media dalam kegiatan merobek dan menggunting sangat efektif untuk meningkatkan keterampilan motorik halus dalam proses pembelajaran yang menarik minat anak dengan berbagai media yang digunakan dalam kegiatan merobek dan menggunting.

\section{- Bagi Peneliti}

Lanjutan Keterampilan motorik halus anak merupakan aspek yang sangat penting bagi perkembangan anak, oleh sebab itu peneliti selanjutnya diharapkan dapat membuat penelitian mengenai keterampilan motorik halus anak melalui berbagai media yang lain yang lebih menarik bagi anak. 


\section{DAFTAR PUSTAKA}

Asri Budiningsih. (2004). Belajar dan Pembelajaran. Yogyakarta: Rineka Cipta.

Dini P. Daeng Sari. (1996). Metode Mengajar di Taman Kanak kanak. Jakarta: Depdikbud.

Cucu Eliyawati. (2005). Pemilihan danPengembanganSumber Belajar untuk Anak Usia Dini. Jakarta: Depdiknas.

Hurlock Elizabeth B. (1978). Perkembangan Anak Jilid 1 Edisi keenam (Med. MeitasariTjandrasa.Terjemahan). Jakarta: Erlangga.

Harun Rasyid, Mansyur \&Suratno. (2009). Assesmen Perkembangan Anak Usia Dini. Jakarta: Depdiknas.

Mistriyanti. (2012). Perkembangan Motorik Halus Anak Usia Dini. Diakses dari http://haurasyalsabila.blogspot.com pada tanggal 8 November 2013, jam 15.00 WIB.

Rochiati Wiriaatmadja. (2006). Metode Penelitian Tindakan Kelas. Bandung: Remaja Rosdakarya.

Slamet Suryanto. (2005). Dasar-dasar Pendidikan Anak Usia Dini. Yogyakarta: Hikayat.

Suharsimi Arikunto. (1992). Prosedur Penelitian. Jakarta: Rineka Cipta. . (2005). Manajemen Penelitian. Jakarta: Rineka Cipta.

Sujati. (2000). Penelitian Tindakan Kelas. Yogyakarta: UNY.

Sukadiyanto. (1997). Penentuan Tahap Kemampuan Motorik Anak SD. Edisi 1 TH III April Majalah Olahraga. Yogyakarta: FPOK Yogyakarta.

Sumantri. (2005). Model Pengembangan Keterampilan Motorik Anak Usia Dini. Jakarta: Depdiknas.

Sumanto. (2005). Pengembangan Kreativitas Seni Rupa Anak TK. Jakarta: Depdiknas.

Suratno. (2005). Pengembangan Kreativitas Anak Usia Dini. Jakarta: Depdiknas.

Tadkiroatun Musfiroh. (2008). Bermain Sambil belajar dan Mengasah Kecerdasan. Jakarta: Depdiknas. 
Toho Cholik Mutahir dan Gusril. (2004). Perkembangan Motorik Pada Masa Anak- anak. Jakarta: Depdikbud. Undang-undang Republik Indonesia No 20 Tahun 2003 Tentang Sistem Pendidikan Nasional. Yogyakarta: Sinar Grafika.

Wina Sanjaya. (2010). Penelitian Tindakan Kelas. Jakarta: Kencana.

Yudha M Saputra dan Rudyanto. (2005). Pembelajaran Kooperatif Untuk Meningkatkan Keterampilan Anak Taman Kanak-kanak. Jakarta: Depdiknas.

Rika Ariyani, Editor Jurnal Literasiologi. Literasi Kita Indonesia. STAI Syekh Maulana Qori. Merangin Bangko.

Sumarto, D. S. (2018). Mewujudkan Sekolah Efektif Melalui Manajemen Mutu. Jurnal Al-Ashlah, 2(1). Diambil dari https://journal.staimaarifjambi.ac.id/index.php/alashlahjournal/article/view/127 